\title{
MODIFICATION AND PSYCHOMETRIC EVALUATION OF THE PETERSON WAR SCALE ${ }^{1,2}$
}

\author{
D. GABRIELLE JONES-WILEY
}

Jackson State Univeristy

ALBERTO F. RESTORI

Department of Educational Psychology
HOWARD B. LEE

Department of Psychology

\author{
California State University, Nortbridge
}

\begin{abstract}
Summary.-A measure on attitudes toward war was administered to 125 student participants at a California university to assess psychometric properties for this scale for possible use in current research. A 5-point scale was substituted for the 2-point one originally. Item analysis indicated 23 of 32 items were viable. Using Cronbach reliability coefficient $\alpha$ and factor analysis, the shortened measure had an internal consistency reliability of .85 . Factor analysis yielded a 4 -factor structure: (1) War is Bad, (2) War is Necessary, (3) Positive Aspects of War, and (4) No Justification. These results indicate this seemingly outdated measure of war attitudes remains useful for current research purposes involving measuring attitudes toward war. However, longitudinal research is necessary.
\end{abstract}

Recent news article and editorials along with the popularity of blogs and websites ${ }^{3}$ reflect widespread interest concerning general attitudes toward war. Some reports ${ }^{4}$ have suggested that the current trend is that of lessened support or favor of war. However, most of these are based on anecdotal information coupled with opinion and informal polls, not empirical scientific research. Sound empirical research needs to be done to establish the validity of these apparent trends.

Measuring scales are needed to evaluate more accurately the attitudes of people toward war. Some researchers may be tempted to construct a new test for this purpose. This long involved process may not be necessary since

\footnotetext{
'Address correspondence to Howard Lee, Department of Psychology, California State University, Northridge, CA 91330-8255, or e-mail (howard.lee@csun.edu).

${ }^{2}$ The authors thank Igor Himelfarb and Miyuki Boluyt for their assistance in collecting data for the first 51 participants of this study.

${ }^{3}$ Bellantoni, C. (2007, May 30, 2007) Antiwar sentiment rises at grassroots level. World Peace Herald. Retrieved June 2, 2007 from http://wpherald.com/articles/4967/2/Antiwar-sentimentrises-at-grassroots-level/DSCC-intends-to-expand-Democratic-majority-in-2008.html; Joyner, J. (2007) Iraq war attitudes. Outside the Beltway. Retrieved July 14, 2007 from hitp://www. outsidethebeltway.com/archives/2007/iraq_war_attitudes/; www.antiwar.com; www.whatreally happened.com.

${ }^{4}$ Lefever, E. W. (2007, February 8, 2007) All Quiet on the Western Front. The Weekly Standard. Retrieved February 8, 2007 from http:/www.weeklystandard.com/Content/Public/ Articles/000/000/013/258tfkdi.asp; Pope Benedict calls wars 'useless slaughters'. (July 23, 2007). The Daily News. Retrieved July 23, 2007 from http://www.dailynews.com/ci_6440101.
}

DOI 10.2466/PR0.101.2.519-524 
there are existing measures of attitudes (see Thurstone, 1932; Shaw \& Wright, 1967; Aliano \& Lester, 1994; Lester, 1994). These can be used by collecting new data using these instruments to determine modern psychometric properties of reliability and validity.

In this study, the authors' retrieved the Peterson War Scale from a book by Shaw and Wright (1967) that reported values of reliability that ranged from .44 to .84 . The study presented here will provide updated information on this scale. This study assesses reliability of the scale and its underlying structure.

MeTHOD

\section{Participants}

One hundred and twenty-five volunteer participants were recruited from sophomore, junior, and senior undergraduate students at a California university. The sample included $76(60.8 \%)$ females and $38(30.4 \%)$ males who reported their sex. Eleven participants $(8.8 \%)$ did not specify their sex. Ages ranged from 19 to 58 years $(M=24.6, S D=5.8)$. Forty-nine $(39.2 \%)$ participants stated that they were white, $75(60 \%)$ stated they were not white, and one person $(0.8 \%)$ did not specify an ethnicity. Ninety-one $(72.8 \%)$ stated they were born in the United States, $33(26.4 \%)$ said they were foreign born, and one $(0.8 \%)$ did not specify a birth place.

Procedure

The participants were asked to complete the original 32-item Peterson War Scale. Peterson developed this scale in 1931 under the direction of Thurstone (1932). The original scale is available in Shaw and Wright (1967). The 32 items had a 2-choice response scale (Agree-Disagree) to measure the attitude toward war. Some sample items from this scale are "War is glorious," "There is no conceivable justification for war," and "International disputes should be settled without war." Shaw and Wright (1967) report a range of reliabilities from .44 to .84 for the scale. The current study replaced the 2-point scale in favor of a 5 -point Likert scale where $1=$ strongly agree and $5=$ strongly disagree. Comrey (1978) and Comrey and Lee (1992) provide the rationale for such a decision. Comrey and Lee (1992) have argued that the use of 2-choice response scales can have the undesirable effect of reducing the size of the correlation coefficient between variables.

For scoring purposes, the 5 -point response scale was reversed for negatively worded items (e.g., $1 \mathrm{~s}$ were now recoded as $5 \mathrm{~s}, 2 \mathrm{~s}$ became $4 \mathrm{~s}$, etc.). An item analysis was performed on the 32 -item scale. Correlations were computed between each item and the total score. Nine of the items had very low correlations $(|r| \leq 30)$. Items 3, 9, 10, 11, 12, 14, 21, 25, and 31 were eliminated from further analysis. The reduced item scale ( 23 items) was analyzed 
using Cronbach alpha reliability coefficient (see Anastasi \& Urbina, 1997) and Comrey's minimum residual factor analysis (Comrey, 1962; Comrey \& Ahumada, 1964) with tandem criteria rotation (Comrey, 1967).

\section{Reliability}

\section{Results}

For the 23-item attitude toward war scale, the Cronbach alpha was .85 . There was no significant difference between women $(M=81.1, S D=13.6)$ and men $(M=79.0, S D=9.8)$ for the total attitude score $(t=0.94, p>.05)$. The Levene test gave a statistically significant difference between the women's and men's group variances $(p<.05)$. An adjustment for this difference did not affect the significance test between means. There was also no significant difference between whites $(M=79.1, S D=13.8)$ and nonwhites $(M=$ $79.8, S D=12.1 ; t=-0.43, p>.05)$. However, there was a significant difference between U.S.-born $(M=81.4, S D=11.9)$ and foreign-born participants $(M=74.9, S D=14.3 ; t=2.4, p<.05)$. The Levene test for both comparisons was not statistically significant $(p>.05)$.

\section{Factor Analysis}

The minimum residual method of factor extraction (Comrey, 1962) yielded 10 factors. These 10 factors were rotated using Criterion 1 of Comrey's Tandem Criteria of rotation (Comrey, 1967). Comrey and Lee (1992) stated that Criterion 1 is useful in assessing the number of retainable factors (Comrey \& Lee, 1992, pp. 198-200). Criterion 1 rotations do not necessarily result in a simple structure solution. Rotating the Criterion 1 factors using Criterion 2 should give a solution that approximates simple structure.

Criterion 1 rotations yielded retainable factors. These factors were rotated using Criterion 2. Several of the items had salient loadings on more than one factor. These variables are not pure factor measures. The first factor consisted of 10 items. This factor could be named "War is Bad." The second factor with 8 items could be named "War is Necessary." The third factor with salient loadings on six items could be named "Positive Aspects of War." The last factor had salient loadings on two items and can be named as "No Justification." The Criterion 2 rotated solution is given in Table 1 along with the communality estimates $\left(b^{2}\right)$, means, and standard deviations for each item.

\section{Discussion}

An item-analysis of the scale using current data provided evidence that nine items of the original scale could be dropped. With the deletion of these items, the Cronbach alpha reliability increased from .80 to .85 . The .85 value obtained for the war scale shows a slightly higher value than the maximum value reported by Shaw and Wright (1967). 
TABLE 1

Loadings, Communalities, Means, and Standard Deviations of Four Fxtracted Factors For Revised Attitude Toward War Scale

\begin{tabular}{|c|c|c|c|c|}
\hline Factor and Item & Loading & $b^{2}$ & $M$ & $S D$ \\
\hline \multicolumn{5}{|l|}{ I. War is Bad } \\
\hline 1. War is hardly necessary in the modern world. & .44 & .41 & 3.2 & 1.3 \\
\hline 2. War is a futile struggle resulting in self-destruction. & .72 & .60 & 3.5 & 1.2 \\
\hline $\begin{array}{l}\text { 4. A host of young men returned from the war } \\
\text { disillusioned and cynical. }\end{array}$ & .68 & .50 & 3.6 & 1.2 \\
\hline 8. War destroys the finest of the nation's manhood. & .53 & .45 & 3.2 & 1.2 \\
\hline 15. War is an unnecessary waste of human life. & .76 & .73 & 3.3 & 1.3 \\
\hline 17. War should be avoided at any cost. & .54 & .45 & 3.4 & 1.3 \\
\hline $\begin{array}{l}\text { 20. The benefits of war are not worth its misery and } \\
\text { suffering. }\end{array}$ & .81 & .82 & 3.3 & 1.3 \\
\hline $\begin{array}{l}\text { 22. War in the modern world is as needless as it is } \\
\text { terrible. }\end{array}$ & .74 & .65 & 3.1 & 1.3 \\
\hline 27. International disputes should be settled without war. & .70 & .66 & 3.9 & 1.2 \\
\hline 28. The soldier suffers terribly and gains nothing. & .61 & .49 & 3.3 & 1.3 \\
\hline \multicolumn{5}{|l|}{ II. War is Necessary } \\
\hline $\begin{array}{l}\text { 5. Another war would be terrible but it might be worth } \\
\text { the price. }\end{array}$ & .64 & .43 & 4.0 & 1.1 \\
\hline $\begin{array}{l}\text { 7. War is sometimes necessary because right is more } \\
\text { important than peace. }\end{array}$ & .77 & .63 & 3.6 & 1.4 \\
\hline 16. Peace and war are both essential to progress. & .65 & .49 & 2.8 & 1.2 \\
\hline $\begin{array}{l}\text { 18. Under some conditions, war is necessary to maintain } \\
\text { justice. }\end{array}$ & .62 & .41 & 2.5 & 1.1 \\
\hline 19. War develops the moral strength of men. & .44 & .42 & 3.9 & 1.0 \\
\hline 26. There can be no progress without war. & .55 & .48 & 4.1 & .9 \\
\hline 29. War is simply murder sanctioned by governments. & -.57 & .53 & 2.5 & 1.3 \\
\hline 32. War stimulates men to their noblest efforts. & .42 & .33 & 3.6 & 9 \\
\hline \multicolumn{5}{|l|}{ III. Positive Aspects of War } \\
\hline 6. War is glotious & .59 & .37 & 4.6 & 6 \\
\hline 19. War develops the moral strength of men. & .40 & .42 & 3.9 & 1.0 \\
\hline 23. Every man should enlist as soon as war is declared. & .61 & .42 & 4.5 & .7 \\
\hline 26. There can be no progress without war. & .41 & .48 & 4.1 & .9 \\
\hline $\begin{array}{l}\text { 30. War is a satisfactory way to solve international } \\
\text { difficulties. }\end{array}$ & .57 & .40 & 4.2 & .8 \\
\hline 32. War stimulates men to their noblest efforts. & .35 & .33 & 3.6 & .9 \\
\hline \multicolumn{5}{|l|}{ IV. No Justification } \\
\hline $\begin{array}{l}\text { 13. Every last one of us should refuse to take part in } \\
\text { any way in any war. }\end{array}$ & .64 & .41 & 2.8 & 1.3 \\
\hline 24. There is no conceivable justification for war. & .83 & .74 & 2.7 & 1.2 \\
\hline
\end{tabular}

The comparison of men and women on the total score was not statistically significant, however, the direction indicated by the means supported the direction found in the literature (Lester, 1994). Women were generally more against war than men. Carnagey and Anderson (2006) found a similar pattern. Erickson $(1944,1948)$ performed a series of studies that yielded no relation between sex and attitudes toward war. 
The comparison of whites with non-whites also yielded no significant difference, with whites being only slightly more in favor of war than nonwhites. Significant differences were noted when comparing those born in the USA and those who were foreign-born. Results suggest individuals born in the USA were more against war than those who were foreign-born.

Factor analysis of the 23-item scale gave four factors and identified problems with Items 19, 26, and 32 which had salient loadings on more than one factor. Hence, these items are more complex than the others and warrant additional study or possible modification. The factor analysis provides additional information about the dimensions underlying attitudes toward war as measured on the Peterson War Scale. However, using the factor structure from an exploratory factor analysis, a confirmatory factor analysis was performed to judge how well the data fit the structure. This additional analysis was not promising as the goodness of fit index (CFI) was .76, and so not a good fit since the value is less than .90 (Brown, 2006). This indicates that further analyses may find a factor structure that would have a better fit to the data.

Perhaps, the statements made by Ericksen (1948) nearly 60 years ago concerning attitudes toward war is still true today. Ericksen at that time observed war attitudes to be very complex and not easily explainable. His studies made comparisons across different groups as those by sex and education, plus those who had a personal loss in war or had served in the military. He found no relations for these characteristics with attitude toward war. Ericksen's research on attitudes before World War 2, during that war, and then afterwards yielded no change in attitudes. However, Carnagey and Andersen (2006) remarked attitudes toward war were unstable. In the aftermath of the September 11, 2001 terrorist attack, people surveyed about their attitude toward war showed a highly favorable attitude. However, Carnagey and Anderson (2006) reported groups were less favorable toward war when they were surveyed a year later. Cohrs, Moschner, Maes, and Kielmann (2005) noted two dimensions involving personal values related to attitudes toward war. One dimension was authoritarianism, and the other was self-enhancement. Those people who scored high on social dominance and high on lack of concern for human loss had the most favorable attitudes toward war.

A follow-up administration of the same 23 -item scale should be administered to people after the current climate of war in Iraq and Afghanistan has changed. Such a follow-up might provide additional confirmation to Ericksen's findings or question their stability.

The current study did demonstrate that an item analysis and the use of a 5-point response scale resulted in an improvement over the original twopoint response scale and the 32 -item scale by providing a shorter instrument and slightly higher internal consistency reliability. 


\section{REFERENCES}

Aliano, M., \& Lester, D. (1994) Attitude toward war in veterans. Psychological Reports, 75, 314.

Anastasi, A., \&Urbina, S. (1997) Psychological testing. (7th ed.) New York: Prentice Hall.

Brown, T. A. (2006) Confirmatory factor analysis for applied research. New York: Guilford.

Carnagey, N. L., \& Anderson, C. A. (2006) Changes in attitudes toward war and violence after September 11, 2001. Aggressive Behavior, 33(2), 118-129.

Cohrs, J. C., Moschner, B., Maes, J., \& Kielmann, S. (2005) Personal values and attitudes toward war. Peace and Conflict: Joumal of Peace Psychology, 11(3), 299-312.

Comrey, A. L. (1962) The minimum residual method of factor analysis. Psychological Reports, $11,15-18$.

Comrey, A. L. (1967) Tandem criteria for analytic rotation in factor analysis. Psychometrika, $32,143-154$

Comrey, A. L. (1978) Common methodological problems in factor analytic studies. Journal of Consulting and Clinical Psychology, 46(4), 648-659.

Comrey, A. L., \& Ahumada, A. (1964) An improved procedure and program for minimum residual factor analysis. Psychological Reports, 15, 91-96.

Comrey, A. L., \& LeE, H. B. (1992) A first course in factor analysis. (2nd ed.) Mahwah, NI: Erlbaum.

Ericksen, S. C. (1944) A skeptical note on the use of attitude scales toward war: II. In 1942. Joumal of Social Psychology, 20, 31-38.

ERICKSEN, S. C. (1948) A skeptical note on the use of attitude scales toward war: III. In 1946. Jounnal of Social Psychology, 27, 79-90.

Lester, D. (1994) Factors affecting student attitudes toward war. Joumal of Social Psychology, $134,541-543$.

Shaw, M. E., \& WRIGHT, J. M. (1967) Scales for the measurement of attitudes. New York: McGraw-Hill.

Thurstone, L. L. (1932) The measurement of social attitudes. Chicago, IL: Univer. of Chicago Press.

Accepted August 20, 2007 